\title{
Limfocytarne zapalenie opon mózgowo-rdzeniowych w przebiegu dokanałowego leczenia liposomalną cytarabiną u chorego na ostrą białaczkę limfoblastyczną
}

\author{
Lymphocytic meningitis after intrathecal liposomal cytarabine \\ in a patient with acute lymphoblastic leukemia
}

\author{
Aleksandra Gołos ${ }^{1}$, Joanna Góra-Tybor ${ }^{1}$, Ewa Lech-Marańda ${ }^{1,2}$, Krzysztof Warzocha ${ }^{1}$ \\ ${ }^{1}$ Klinika Hematologii, Instytut Hematologii i Transfuzjologii, Warszawa \\ ${ }^{2}$ Klinika Hematologii i Transfuzjologii, Centrum Medyczne Kształcenia Podyplomowego, Warszawa
}

\begin{abstract}
Streszczenie
Zajecie ośrodkowego uktadu nerwowego (OUN) w momencie rozpoznania ostrej biataczki limfoblastycznej (ALL) dotyczy okoto 5\% chorych i jest czynnikiem ztego rokowania. Wprowadzenie profilaktyki zmniejszyto czestość zajecia OUN w nawrocie choroby z 30\% do okoto 10\%. Liposomalna cytarabina (Ara-C) jest postacia leku do podawania dokanatowego o przedtużonym uwalnianiu; jej okres póttrwania w plynie mózgowo-rdzeniowym wynosi okoto 2 tygodni. Stosuje sie ja w profilaktyce i w leczeniu zajecia OUN. W badaniach klinicznych wykazano jej przewage nad klasyczna forma zarówno pod względem odsetków odpowiedzi, jak i jakości życia chorych. Jednak w porównaniu z klasyczna terapia trójlekowa (metotreksat, klasyczna Ara-C, deksametazon) stosowanie liposomalnej Ara-C wiaże sie $z$ wyżsym ryzykiem neurotoksyczności. W artykule zaprezentowano opis przypadku 47-letniego chorego na ALL pre-T, u którego po 3 podaniach liposomalnej Ara-C rozwinęto sie bezobjawowe limfocytarne zapalenie opon mózgowo-rdzeniowych z cytoza siegajaca

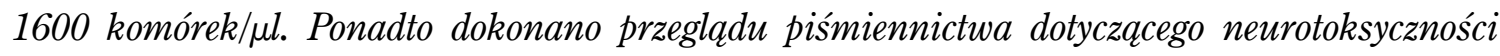
liposomalnej Ara-C.
\end{abstract}

Słowa kluczowe: ostra białaczka limfoblastyczna, liposomalna cytarabina, neurotoksyczność, zapalenie opon mózgowo-rdzeniowych

Hematologia 2017; 8, 3: 228-233

\begin{abstract}
Central nervous system (CNS) involvement at diagnosis of acute lymphoblastic leukemia (ALL) is found in approximately 5\% of patients and is a poor prognosis factor. Introduction of prophylactic strategies reduced involvements rate from $30 \%$ to $10 \%$ at relapse. Prophylactic regimens include: intrathecal chemotherapy (methotrexate, cytarabine [Ara-C], dexamethasone), irradiation of the whole brain, and systemic chemotherapy penetrating to CNS. Liposomal Ara-C is a prolonged-release formulation of Ara-C dedicated to intrathecal use. Its half-time is about 2 weeks. It has been used in prophylaxis and treatment regimens. Clinical trials proved its better efficacy and patients' quality of life than its standard formulation. However, in comparison with classic triple intrathecal therapy, using liposomal Ara-C may have higher risk of neurotoxicity. In the paper we report
\end{abstract}

Adres do korespondencji: Aleksandra Gołos, Klinika Hematologii, Instytut Hematologii i Transfuzjologii, ul. Indiry Gandhi 14, 02-776 Warszawa, tel. 223496 334, faks 223496 335, e-mail: agolos@ihit.waw.pl 


\begin{abstract}
a case of 47-years-old patient with pre-T ALL who after third injection of liposomal Ara-C developed a symptomless lymphocytic meningitis with the maximal cytosis in cerebrospinal fluid of $1600 \mathrm{cells} / \mu \mathrm{l}$. The review of the literature on neurotoxicity of liposomal Ara-C is hereby presented.
\end{abstract}

Key words: acute lymphoblastic leukemia, liposomal cytarabine, neurotoxicity, meningitis

Hematologia 2017; 8, 3: 228-233

\section{Wprowadzenie}

Ostra białaczka limfoblastyczna (ALL, acute lymphoblastic leukemia)/chłoniak limfoblastyczny (LBL, lymphoblastic lymphoma) jest nowotworem wywodzących się $z$ komórek linii rozwojowej limfocytów B lub T. Nowotworowe limfoblasty mogą ulegać ekspansji w szpiku kostnym, węzłach chłonnych oraz innych narządach, w tym ośrodkowym układzie nerwowym (OUN). Zajęcie OUN w momencie rozpoznania dotyczy około $5 \%$ chorych i jest czynnikiem złego rokowania [1]. Klasycznymi czynnikami ryzyka zajęcia OUN są zwiększona aktywność dehydrogenazy mleczanowej (LDH, lactate dehydrogenase), wysoka leukocytoza (WBC, white blood count), białaczka $z$ dojrzałych komórek $\mathrm{B}$, białaczka T-komórkowa i białaczka $\mathrm{z}$ obecnością translokacji $B C R-A B L 1$ [2]. Strategie postępowania profilaktycznego i leczniczego obejmują chemioterapię dokanałową (i.t., intrathecal), radioterapię OUN i chemioterapię systemową z zastosowaniem leków, które wykazują zdolność przenikania przez barierę krew-mózg [3]. Wprowadzenie profilaktyki zmniejszyło częstość wtórnego zajęcia OUN z 30\% do około $10 \%$ pacjentów [3]. W chemioterapii i.t. rutynowo stosuje się trzy leki - metotreksat, cytarabinę (Ara-C, arabinoside cytosine) i deksametazon. Dwa spośród nich, metotreksat i Ara-C, są aktywne w fazie $\mathrm{S}$ cyklu komórkowego, a ich okres półtrwania w płynie mózgowo-rdzeniowym (CSF, cerebrospinal fluid) wynosi $24 \mathrm{~h} \mathrm{w}$ przypadku cytarabiny i $30 \mathrm{~h} \mathrm{w}$ przypadku metotreksatu [4]. $\mathrm{O}$ ile w ramach schematów profilaktyki zakłada się kilka podań i.t. rozłożonych w czasie, o tyle w przypadku zajęcia OUN wymagane jest częstsze podawanie leków, aż do 2-krotnie potwierdzonej eradykacji komórek ALL.

Biorąc pod uwagę właściwości farmakokinetyczne i aktywność leków tylko w fazie S cyklu komórkowego, by leczenie było skuteczne, konieczne jest powtarzanie punkcji lędźwiowych co 48-72 h. W przypadku jednoczesnego leczenia systemowego utrzymanie częstości dawek chemioterapeutyków i.t. jest utrudnione ze względu na czasowe przeciwwskazania do wykonania punkcji lędźwiowej.
Liposomalna Ara-C jest roztworem cytarabiny o przedłużonym uwalnianiu; jej okres półtrwania w CSF wynosi około 2 tygodni [5]. W badaniach I fazy wykazano jej istotną przewagę pod względem właściwości farmakokinetycznych nad postacią standardową [6]. W kolejnych badaniach, u chorych $z$ chłoniakowym zajęciem opon mózgowo-rdzeniowych otrzymujących liposomalną Ara-C, wykazano większy odsetek uzyskiwanych odpowiedzi i lepszą jakość życia (QoL, quality of life) w porównaniu $z$ pacjentami, u których stosowano postać standardową [7]. Należy jednak podkreślić, że wśród chorych leczonych liposomalną Ara-C istotnie częściej raportowano zaburzenia neurologiczne inne niż bóle głowy. Najczęstszym $z$ nich było tak zwane chemiczne zapalenie pajęczynówki (chemical arachnoiditis), które dotyczyło około $60 \%$ leczonych bez jednoczesnego stosowania deksametazonu systemowo [7]. Włączenie glikokortykosteroidu zmniejszyło częstość tego powikłania do kilkunastu procent chorych i stało się podstawą wprowadzenia do charakterystyki produktu leczniczego tego zalecenia [8]. Opisywano również inne ciężkie powikłania neurologiczne, takie jak zespół ogona końskiego, zaburzenia świadomości do śpiączki włącznie czy encefalopatia [9-11].

$\mathrm{W}$ artykule przedstawiono opis przypadku chorego na chłoniaka limfoblastycznego T-komórkowego, u którego po zastosowaniu trzeciej dawki liposomalnej Ara-C wystąpiło bezobjawowe limfocytarne zapalenie opon mózgowo-rdzeniowych.

\section{Opis przypadku}

Mężczyzna w wieku 47 lat został przyjęty do kliniki hematologii w styczniu 2017 roku w celu przeprowadzenia diagnostyki leukocytozy oraz limfadenopatii szyjnej. Badania dodatkowe wykazały WBC 49 G/l, niewielkiego stopnia niedokrwistość ze stężeniem hemoglobiny $12 \mathrm{~g} / \mathrm{dl}$ i małopłytkowość $59 \mathrm{G} / 1$. W rozmazie krwi obwodowej odsetek blastów wynosił $32 \%$. Badania biochemiczne ujawniły hiperurykemię $8,3 \mathrm{mg} / \mathrm{dl}$ oraz zwiększoną aktywność LDH. Wykonana tomografia komputerowa (CT, computed tomography) całego ciała uwidoczniła uogólnioną lifmadenopatię o maksymalnej wielkości 
węzłów $50 \times 67 \mathrm{~mm}$. Ponadto opisano naciek węzłowy wielkości $28 \times 63 \times 130 \mathrm{~mm}$ w śródpiersiu przednim oraz niewielką ilość wolnego płynu w jamie opłucnowej. W badanym aspiracie szpiku kostnego stwierdzono 97,5\% komórek blastycznych o immunofenotypie pre-T (CD7+ sCD3- CD2 + CD5+ CD4- CD8+/- CD1a-/+ HLA-DR-CD34-/+ CD45+ CD52-CD99+ TdT + cyCD3+). Nie określono kariotypu szpiku kostnego ze względu na brak metafaz. Metodą fluorescencyjnej hybrydyzacji in situ (FISH, fluorescent in situ hybridisation) wykluczono obecność transkryptów MLL-AF4 t(4;11)(q21;q23) i SIL-TAL1 $\operatorname{del}(1)(\mathrm{p} 32 ; \mathrm{p} 32)$.

Na podstawie wyników badań u pacjenta rozpoznano ALL pre-T. Chorego zakwalifikowano do leczenia według programu PALG 2006 (Polish Adult Leukemia Group). W okresie przedleczenia prednizonem wykonano punkcję lędźwiową $z$ podaniem liposomalnej Ara-C i.t. Przy podaniu stosowano deksametazon ogólnoustrojowo w celu profilaktyki chemicznego zapalenia pajęczynówki. Wynik badania ogólnego CSF był prawidłowy; cytoza wynosiła 4 komórki $\mu$ l. W badaniu immunofenotypowym $2,4 \%$ wszystkich komórek stanowiły komórki pre-T ALL. Zgodnie z protokołem leczenia w okresie indukcji ponownie wykonano punkcję lędźwiową z podaniem liposomalnej Ara-C i.t. W badaniu immunofenotypowym CSF nie stwierdzono patologicznych komórek. W wyniku chemioterapii indukującej chory uzyskał całkowitą remisję (CR) bez choroby resztkowej (MRD, minimal residual disease). Pacjenta zakwalifikowano do chemioterapii konsolidującej, w trakcie której otrzymał on po raz trzeci liposomalną Ara-C i.t. Badanie ogólne i immunofenotypowe CSF pozostawały prawidłowe. W CSF pobranym podczas czwartej punkcji lędźwiowej z podaniem liposomalnej Ara-C stwierdzono cytozę 120 komórek/ $\mu$ l. Immunofenotyp komórek odpowiadał odczynowym limfocytom T (CD45+87,7\%, CD3+75\%, komórki NK [naturalnej cytotoksyczności] Cd16+CD3-12,7\%, makrofagi/monocyty CD14+10\%, limfocyty B CD19+ 0\%) - stanowiły one $97 \%$ wszystkich komórek. Nie zidentyfikowano komórek ALL. W badaniu neurologicznym chorego nie stwierdzono żadnych odchyleń od stanu prawidłowego. Zaplanowano powtórną diagnostykę za 2 tygodnie. W czasie pobytu chorego w domu wystąpił epizod gorączki do $40^{\circ} \mathrm{C}$, bez innych cech aktywnej infekcji; pacjent otrzymywał cefuroksym doustnie przez 7 dni. Uzyskano ustąpienie gorączki, utrzymywała się nieznacznie podwyższona temperatura ciała (maks. $37,2^{\circ} \mathrm{C}$ ). Przy przyjęciu do kliniki pacjent był w dobrym stanie ogólnym, w badaniu przedmiotowym nie stwierdzono cech infekcji, nie miał objawów neurologicznych. Morfologia krwi oraz badania biochemiczne były prawidłowe. Wykonano diagnostyczną punkcje lędźwiową; w badaniu ogólnym CSF stwierdzono cytozę 1080 komórek/ $/ \mu 1$, podwyższone stężenie białka $-362 \mathrm{mg} / \mathrm{dl}$, dodatnie odczyny None-Appelta i Pandy'ego. Immunofenotyp nadal odpowiadal limfocytom odczynowym, nie stwierdzono komórek ALL. Posiew CSF pozostawał jałowy. Metodą reakcji łańcuchowej polimerazy (PCR, polymerase chain reaction) nie wykryto materiału genetycznego wirusów Epsteina-Barr ani cytomegalii. Wykonane CT głowy z podaniem środka kontrastowego poza torbielą pajęczynówki nie ujawniło nieprawidłowości. Do leczenia włączono ceftriakson, wankomycynę, trimetoprim/ /sulfametoksazol, acyklowir i flukonazol, następnie pacjenta $z$ podejrzeniem neuroinfekcji skierowano na dalszą diagnostykę na oddział chorób zakaźnych.

W CSF pobranym przy przyjęciu na oddział chorób zakaźnych cytoza zwiększyła się do 1630 komórek/ $\mu$ l. W badaniu rezonansu magnetycznego (MRI, magnetic resonance imaging) głowy $z$ kontrastem potwierdzono obecność torbieli pajęczynówki, poza tym nie uwidoczniono zmian patologicznych. Posiewy CSF w kierunku zakażeń bakteryjnego i grzybiczego były jałowe. W bakterioskopii bezpośredniej nie stwierdzono obecności prątków kwasoopornych. W badaniu PCR wykluczono obecność materiału genetycznego tuberculosis spp., cryptococcus neoformans, enterowirusów, adenowirusów, ludzkiego wirusa opryszczki (HHV, human herpes virus) 6, HHV7 i HHV8. W teście immunoenzymatycznym wykluczono boreliozę. Kontynuowano leczenie przeciwinfekcyjne. Po około 2 tygodniach leczenia w badaniu ogólnym CSF cytoza wynosiła 208 komórek/ $\mu$ l. Pacjenta wypisano $z$ rozpoznaniem limfocytarnego zapalenia opon mózgowo-rdzeniowych. W kontrolnym badaniu po kolejnych 2 tygodniach stwierdzono dalsze zmniejszenie cytozy, pacjenta ponownie skierowano do kliniki hematologii. Ze względu na bezobjawowy przebieg, brak identyfikacji czynnika etiologicznego i redukcję cytozy w kolejnych badaniach zadecydowano o podaniu trzeciego cyklu konsolidującego. Nie obserwowano istotnych powikłań leczenia. W profilaktyce zajęcia OUN zastosowano metotreksat, Ara-C oraz deksametazon i.t. Cytoza w CSF wynosiła 7 komórek $/ \mu 1$.

Po zakończeniu leczenia konsolidującego u pacjenta stwierdzono obecność $\mathrm{MRD}(+)$ ocenianej metodą cytometrii przepływowej w szpiku kostnym $(0,18 \%)$. Badanie pozytonowej tomografii emisyj- 
nej (PET, positron emission tomography) wykazało całkowitą remisję metaboliczną, w badaniu CSF nie stwierdzono komórek ALL. Ze względu na $\mathrm{MRD}(+)$ pacjenta zakwalifikowano do chemioterapii według schematu miniFLAM (fludarabina, Ara-C, mitoksantron). Rozpoczęto poszukiwania dawcy szpiku.

\section{Dyskusja}

W 1999 roku amerykańska Agencja ds. Żywności i Leków (FDA, Food and Drug Administration) zarejestrowała liposomalną Ara-C do leczenia i.t. zajęcia opon mózgowo-rdzeniowych w chłoniakach [9]. Stopniowe uwalnianie Ara-C z liposomów do CSF powoduje około 40-krotne wydłużenie czasu na jej ekspozycję w porównaniu $z$ klasyczną postacią [10]. Dzięki temu można wydłużyć minimalny odstęp między kolejnymi nakłuciami lędźwiowymi do około 2 tygodni $[5,10]$. Badanie I fazy dotyczyło 18 dzieci ze wznową w OUN (zarówno ALL, jak i guzów litych) [11]. W badaniu wykazano wysoką skuteczność i bezpieczeństwo leczenia liposomalną Ara-C i.t., nie obserwując istotnej neurotoksyczności leczenia [11]. W kolejnych randomizowanych badaniach pacjenci leczeni liposomalną Ara-C i.t. odnosili korzyść kliniczną w postaci większego odsetka uzyskiwanych odpowiedzi oraz znacząco lepszej QoL ze względu na rzadsze wykonywanie punkcji lędźwiowych [9]. Najczęstszymi działaniami niepożądanymi leczenia były bóle głowy i chemiczne zapalenie pajęczynówki. Wprowadzenie kortykosteroidów do schematów terapii znacznie zmniejszyło odsetek ostatniego powikłania [8]. Parasole i wsp. [12] analizowali neurotoksyczność liposomalnej Ara-C w populacji 30 dzieci z nawrotem ALL w OUN. Dwudziestu siedmiu pacjentów otrzymywało liposomalną Ara-C i.t. łącznie $z$ leczeniem systemowym penetrującym do OUN (wysokodawkowany metotreksat i Ara-C). Odsetek uzyskanych CR wynosił $89 \%$; troje dzieci uzyskało odpowiedź częściową (PR, partial remission). Toksyczność neurologiczną 3. i 4. stopnia obserwowano u czworga dzieci (13\%) i wystąpiła ona pod postacią zespołu odwracalnej tylnej encefalopatii, zeza z towarzyszącym wzmożonym napięciem mięśniowym kończyn dolnych oraz napadu drgawkowego $\mathrm{z}$ afazją $i$ ataksji. $\mathrm{U} 2$ pacjentów wystąpienie objawów neurologicznych nie miało jednoznacznego związku z leczeniem i.t., ponieważ wcześniej wystąpiły czynniki, które również mogły wywołać wyżej wymienione objawy (krwawienie podpajęczynówkowe $z$ napadem drgawkowym, progresja choroby podstawowej w OUN) [12].
W kolejnych badaniach potwierdzano przewagę liposomalnej Ara-C nad klasyczną terapią i.t. zarówno pod względem właściwości farmakokinetycznych, jak i skuteczności leczenia również u dorosłych pacjentów [13] Spowodowało to rozpowszechnienie stosowania tej formy leku w hematologii i onkologii. Jednakże u chorych dorosłych obserwowano większą neurotoksyczność leku niż w populacji dzieci. Uważa się, że tolerancja leku u dzieci jest lepsza między innymi w związku krótszym okresem półtrwania w CSF, wynoszący $50-57 \mathrm{~h}$ w porównaniu $z$ dorosłymi (ok. 140 h), a także dostosowanie dawki leku do wieku i stosowanie deksametazonu i.t. [5, 14, 15]. Jabbour i wsp. [16] analizowali skuteczność i toksyczność liposomalnej Ara-C w grupie 31 pacjentów $\mathrm{z}$ nowo rozpoznaną ALL i chłoniakiem/białaczką Burkitta (BL, Burkitt lymphoma/leukemia) bez zajęcia OUN. Wszyscy otrzymywali liposomalną Ara-C albo standardową chemioterapię i.t. (cytarabina, metotreksat, deksametazon) jako profilaktykę, łącznie $z$ naprzemiennymi schematami chemioterapii systemowej - hyperCVAD (hiperfrakcjonowany cyklofosfamid, winkrystyna, doksorubicyna i deksametazon) i MA (wyskodawkowane metotreksat z Ara-C). Wszyscy chorzy otrzymywali przez 5 dni deksametazon dożylnie, począwszy od dnia wykonania nakłucia lędźwiowego. Najczęstszymi działaniami niepożądanymi były bóle głowy - dotyczyły $39 \%$ pacjentów. Pięciu chorych (16\%) doświadczyło ciężkich powikłań neurologicznych (3. i 4. stopnia) pod postacią napadu drgawkowego, zespołu pseudoguza mózgu ze wzrostem ciśnienia wewnątrzczaszkowego (ICP, intracranial pressure) z postępującym upośledzeniem wzroku, zespołu ogona końskiego, tylnej encefalopatii pochodzenia naczyniowego. Objawy wystapily po 3-6 podaniach liposomalnej Ara-C. U wszystkich pacjentów prowadzono diagnostykę w kierunku przyczyn obserwowanych objawów — nie znaleziono patologii, które mogły leżeć u ich podstawy, a toksyczność uznano za związaną $z$ liposomalną Ara-C. Ze względu na te powikłania badanie ukończono przedwcześnie.

$Z$ kolei w dużej retrospektywnej analizie Polskiej Grupy Badawczej Chłoniaków (PLRG, Polish Lymphoma Research Group), obejmującej 120 chorych na chłoniaki, obciążone dużym ryzykiem zajęcia OUN, nie obserwowano ciężkich powikłań neurologicznych po podaniu liposomalnej Ara-C [17]. Ogółem działania niepożądane wystąpiły u 79,2\% chorych, ale większość $z$ nich w stopniu 1 lub 2. Najczęściej opisywano bóle głowy $(69,2 \%)$, nudności $(20,8 \%)$ i gorączkę (16,7\%). U 2 chorych stwierdzono łagodnie przebiegający zespół ogona 
końskiego, głównie w postaci zaburzeń czucia, bez objawów nietrzymania moczu, który ustąpił bez leczenia po kilku dniach. Działania niepożądane w stopniu 3. opisano u 6\% pacjentów, najczęstszymi były bóle głowy [17].

W badaniu grupy austriackiej opisano 40 chorych na ALL bez zajęcia OUN przy rozpoznaniu, którym w ramach profilaktyki podawano liposomalną Ara-C [18]. Mediana liczby podań leku wynosiła 2 na jednego pacjenta (zakres 1-6). Jedynym działaniem niepożądanym obserwowanym u 2 chorych były bóle głowy 2 . stopnia [18].

Grupa hiszpańska opisała neurotoksyczność u 4 z 14 chorych na chłoniaki nie-Hodgkina (NHL, non-Hodgkin lymphoma) leczonych liposomalną Ara-C [19]. U wszystkich wystąpiły objawy zespołu ogona końskiego, dodatkowo u jednego chorego obserwowano wzrost ICP. Mediana liczby kursów liposomalnej Ara-C wynosiła 3,5 (zakres 2-6), a czas od ostatniego nakłucia lędźwiowego do wystąpienia objawów - 4-12 dni.

Kolejne opisy wystąpienia neurotoksyczności dotyczyły pojedynczych przypadków. Lunskens i wsp. [20] opisali wzrost ICP u 27-letniego chorego na ALL $z$ wyjściowym zajęciem OUN. Dzień po trzeciej dawce liposomalnej Ara-C wystąipiły bóle głowy wraz z bólem odcinka lędźwiowo-krzyżowego kręgosłupa, $z$ objawami oponowymi. Po 5 dniach dołączyło się podwójne widzenie. W wykonanej diagnostycznej punkcji lędźwiowej stwierdzono zwiększone ciśnienie wypływu CSF. W diagnostyce wykluczono infekcyjne przyczyny podwyższonego ICP. Po zastosowaniu ogólnoustrojowych wysokodawkowanych glikokortykosteroidów uzyskano całkowite wycofanie się objawów [20].

W piśmiennictwie opisywano również przykłady neurotoksyczności w trakcie leczenia liposomalną Ara-C u chorych na nowotwory lite. Butto i wsp. [21] opisali przypadek piorunującego chemicznego zapalenia opon i komór mózgowych u 56-letniej chorej na raka gruczołowego piersi $\mathrm{w}$ IV stadium zaawansowania, $z$ zajęciem opon mózgowo-rdzeniowych. U pacjentki wcześniej nie obserwowano żadnych objawów neurologicznych. W przeciwieństwie do wyżej opisywanych chorych pierwsze objawy pod postacią bólów głowy pojawiły się natychmiast po zakończeniu zabiegu. U chorej pojawiły się pogłębiające się ilościowe zaburzenia świadomości wraz $z$ reakcją zgięciową kończyn górnych i wyprostną kończyn dolnych. W CT głowy uwidoczniono uogólniony obrzęk mózgu, zmniejszenie rezerwy płynowej oraz ubytek w istocie szarej. Chora zmarła 12 godzin po podaniu leku.
U opisywanego pacjenta po trzecim podaniu liposomalnej Ara-C stwierdzono podwyższoną limfocytozę w CSF. W badaniu immunofenotypowym wykazano obecność limfocytów odczynowych, bez obecności komórek białaczkowych. Wykluczono przyczyny infekcyjne opisywanych zmian, za prawdopodobny uznając związek limfocytozy z podaniem liposomalnej Ara-C i.t.

\section{Podsumowanie}

Liposomalna Ara-C jest bardzo skuteczna zarówno w leczeniu, jak i profilaktyce zajęcia OUN w przebiegu różnych nowotworów. Jednak jej neurotoksyczność jest istotnie większa niż klasycznej terapii trójlekowej metotreksatem, krótkodziałającą Ara-C i deksametazonem. Zastosowanie deksametazonu i unikanie podawania liposomalnej Ara-C jednoczasowo $z$ dużymi dawkami cytostatyków przenikających do OUN, tj. metotreksatu i Ara-C, pozwala istotnie zmniejszyć toksyczność leczenia.

Zmiany w CSF stwierdzane u opisanego pacjenta wymagały różnicowania między białaczkowym zajęciem CSF a odczynową limfocytozą związaną $z$ neuroinfekcją lub podaniem leku. Podstawowe badania służące ustaleniu etiologii zmian to badanie immunofenotypowe limfocytów oraz badania bakteriologiczne. Właściwe ustalenie przyczyn limfocytarnego zapalenia opon pozwoliło na wybór odpowiedniej strategii leczenia u chorego.

\section{Piśmiennictwo}

1. Reman O, Pigneux A, Huguet F, et al. GET-LALA group. Central nervous system involvement in adult acute lymphoblastic leukemia at diagnosis and/or at first relapse: results from the GETLALA group. Leuk Res. 2008; 32(11): 1741-1750, doi: 10.1016/j. leukres.2008.04.011, indexed in Pubmed: 18508120.

2. Lazarus HM, Richards SM, Chopra R, et al. Medical Research Council (MRC)/National Cancer Research Institute (NCRI) Adult Leukaemia Working Party of the United Kingdom and the Eastern Cooperative Oncology Group. Central nervous system involvement in adult acute lymphoblastic leukemia at diagnosis: results from the international ALL trial MRC UKALL XII/ECOG E2993. Blood. 2006; 108(2): 465-472, doi: 10.1182/blood-2005-11-4666, indexed in Pubmed: 16556888.

3. Jabbour E, Thomas D, Cortes J, et al. Central nervous system prophylaxis in adults with acute lymphoblastic leukemia: current and emerging therapies. Cancer. 2010; 116(10): 2290-2300, doi: 10.1002/cncr.25008, indexed in Pubmed: 20209620.

4. Bleyer WA, Dedrick RL. Clinical pharmacology of intrathecal methotrexate. I. Pharmacokinetics in nontoxic patients after lumbar injection. Cancer Treat Rep. 1977; 61(4): 703-708, indexed in Pubmed: 577895.

5. Murry DJ, Blaney SM. Clinical pharmacology of encapsulated sustained-release cytarabine. Ann Pharmacother. 2000; 34(10): 1173-1178, doi: 10.1345/aph.19347, indexed in Pubmed: 11054987. 
6. Kim S, Chatelut E, Kim JC, et al. Extended CSF cytarabine exposure following intrathecal administration of DTC 101. J Clin Oncol. 1993; 11(11): 2186-2193, doi: 10.1200/JCO.1993.11.11.2186, indexed in Pubmed: 8229133.

7. Glantz MJ, LaFollette S, Jaeckle KA, et al. Randomized trial of a slow-release versus a standard formulation of cytarabine for the intrathecal treatment of lymphomatous meningitis. J Clin Oncol. 1999; 17(10): 3110-3116, doi: 10.1200/JCO.1999.17.10.3110, indexed in Pubmed: 10506606.

8. Chamberlain MC, Khatibi S, Kim JC, et al. Treatment of leptomeningeal metastasis with intraventricular administration of depot cytarabine (DTC 101). A phase I study. Arch Neurol. 1993; 50(3): 261-264, doi: 10.1001/archneur.1993.00540030027009, indexed in Pubmed: 8442704.

9. Glantz MJ, LaFollette S, Jaeckle KA, et al. Randomized trial of a slow-release versus a standard formulation of cytarabine for the intrathecal treatment of lymphomatous meningitis. J Clin Oncol. 1999; 17(10): 3110-3116, doi: 10.1200/JCO.1999.17.10.3110, indexed in Pubmed: 10506606.

10. Chamberlain MC, Kormanik P, Howell SB, et al. Pharmacokinetics of intralumbar DTC-101 for the treatment of leptomeningeal metastases. Arch Neurol. 1995; 52(9): 912-917, doi: 10.1001/ /archneur.1995.00540330094020, indexed in Pubmed: 7661730.

11. Bomgaars L, Geyer JR, Franklin J, et al. Phase I trial of intrathecal liposomal cytarabine in children with neoplastic meningitis. J Clin Oncol. 2004; 22(19): 3916-3921, doi: 10.1200/JCO.2004.01.046, indexed in Pubmed: 15459213.

12. Parasole R, Petruzziello F, Messina C, et al. Toxicity and efficacy of intrathecal liposomal cytarabine in children with leukemia/lymphoma relapsing in the central nervous system: a retrospective multicenter study. Leuk Lymphoma. 2015; 56(3): 650-655, doi: 10.3109/10428194.2014.927456, indexed in Pubmed: 24882262.

13. Benesch M, Sovinz P, Krammer B, et al. Feasibility and toxicity of intrathecal liposomal cytarabine in 5 children and young adults with refractory neoplastic meningitis. J Pediatr Hematol Oncol. 2007; 29(4): 222-226, doi: 10.1097/MPH.0b013e318041f112, indexed in Pubmed: 17414563.

14. Parasole R, Menna G, Marra N, et al. Efficacy and safety of intrathecal liposomal cytarabine for the treatment of menin- geal relapse in acute lymphoblastic leukemia: experience of two pediatric institutions. Leuk Lymphoma. 2008; 49(8): 1553-1559, doi: 10.1080/10428190802216749, indexed in Pubmed: 18766969.

15. Peyrl A, Sauermann R, Traunmueller F, et al. Pharmacokinetics and safety of intrathecal liposomal cytarabine in children aged $<3$ years. Clin Pharmacokinet. 2009; 48(4): 265-271, doi: 10.2165/00003088-200948040-00004, indexed in Pubmed: 19492871.

16. Jabbour E, O'Brien S, Kantarjian H, et al. Neurologic complications associated with intrathecal liposomal cytarabine given prophylactically in combination with high-dose methotrexate and cytarabine to patients with acute lymphocytic leukemia. Blood. 2007; 109(8): 3214-3218, doi: 10.1182/blood-2006-08-043646, indexed in Pubmed: 17209054.

17. Jurczak W, Kroll-Balcerzak R, Giebel S, et al. Liposomal cytarabine in the prophylaxis and treatment of CNS lymphoma: toxicity analysis in a retrospective case series study conducted at Polish Lymphoma Research Group Centers. Med Oncol. 2015; 32(4): 90, doi: 10.1007/s12032-015-0520-3, indexed in Pubmed: 25716885 .

18. Valentin A, Troppan K, Pfeilstöcker M, et al. Safety and tolerability of intrathecal liposomal cytarabine as central nervous system prophylaxis in patients with acute lymphoblastic leukemia. Leuk Lymphoma. 2014; 55(8): 1739-1742, doi: 10.3109/10428194.2013. 853765, indexed in Pubmed: 24138308.

19. Gállego Pérez-Larraya J, Palma JA, Carmona-Iragui M, et al. Neurologic complications of intrathecal liposomal cytarabine administered prophylactically to patients with non-Hodgkin lymphoma. J Neurooncol. 2011; 103(3): 603-609, doi: 10.1007/s11060-0100428-x, indexed in Pubmed: 20953897.

20. Lunskens S, Lammertijn L, Deeren D, et al. Intracranial hypertension following intrathecal administration of liposomal cytarabine. J Neurol. 2011; 258(1): 162-163, doi: 10.1007/s00415-0105693-2, indexed in Pubmed: 20706845.

21. Butto A, Al-Holou WN, Junck L, et al. Fulminant chemical ventriculomeningitis following intrathecal liposomal cytarabine administration. J Clin Neurosci. 2011; 18(10): 1417-1418, doi: 10.1016/j. jocn.2011.03.006, indexed in Pubmed: 21764318. 